https://dx.doi.org/10.4314/ijs.v20i2.14

Ife Journal of Science vol. 20, no. 2 (2018)

\title{
ORGANOLEPTIC AND CHEMICAL ASSESSMENT OF TWO FROZEN MARINE FISHES OBTAINED FROM MARKETS IN FOUR AGRICULTURAL ZONES OF OYO STATE, NIGERIA
}

\author{
Fawole, O. O.* $*^{1}$, Oyelese, O. A. ${ }^{2}$, Etim, E. U. ${ }^{3}$ \\ ${ }^{1}$ Department of Aquaculture and Fisheries Management, University of Ibadan, Ibadan, Nigeria \\ ${ }^{2}$ Department of Aquaculture and Fisheries Management, University of Ibadan, Ibadan, Nigeria. E mail: \\ segunoyelese@yahoo.co.uk \\ ${ }^{3}$ Department of Chemistry, University of Ibadan, Ibadan, Nigeria. Email: etim242@yahoo.com \\ Corresponding Author's e-mail: fawila2000@yahoo.co.uk; Phone Number: +23480 35002060
}

(Received: 14th August, 2017; Accepted: 7th July, 2018)

\section{ABSTRACT}

\begin{abstract}
Sensory and non-sensory assessment of frozen fish: Sardinella species and Micromesistiuspoutassou obtained from four Agricultural Development Programme (ADP) zones (Ibadan/Ibarapa, Ogbomoso, Oyo and Saki) of Oyo State were carried out. Overall acceptability was based on 7-point Hedonic scale (very much liked (7) - very much disliked (1). Chemical tests [Hypoxanthine (Hx), Peroxide value (PV), Trimethylamine (TMA) and Free fatty acid (FFA)] were carried out using standard methods. Data were analyzed using the mean, standard deviation and t- test.Overall acceptability of the two frozen fish species was between $5.47 \pm 0.20$ and $5.90 \pm 0.08$. Hx values varied between $22.15 \pm 1.04$ and $25.96 \pm 0.53 \mathrm{mg} / 100 \mathrm{~g}$ fish for Sardinella spp. and $M$. poutassou respectively. The values recorded for both Sardinella spp. and $M$. poutassou were between $17.48 \pm 0.81$ and $19.79 \pm 1.03 \mathrm{meq} / \mathrm{kg}$ for PV; $19.03 \pm 065$ and $23.63 \pm 0.60 \mathrm{mg} / 100 \mathrm{~g}$ fish for TMA and between $1.38 \pm 0.07 \%$ and $1.85 \pm 0.31 \%$ for FFA respectively. In both Sardinella spp. and M. Poutassou respectively, Oyo Zone had the least PV (17.48 \pm 0.81 ; $17.90 \pm 0.60 \mathrm{meq} / \mathrm{kg})$, TMA level $(20.58 \pm 0.90 ; 19.03 \pm 0.65 \mathrm{mg} / 100 \mathrm{~g})$. Sardinella spp. samples from the Ogbomoso Zone had highest PV $(18.83 \pm 0.60 \mathrm{meq} / \mathrm{kg})$, FFA $(1.85 \pm 0.13 \%)$ and TMA $(23.63 \pm 0.60 \mathrm{mg} / 100 \mathrm{~g})$ levels, and also the highest FFA values $(1.81 \pm 0.19 \%)$ in $M$. poutassou. Hypoxanthine and TMA valueswere significantly different in the Sardinella spp. and $M$. poutassou samples across the zones, respectively.Quality of frozen fish was best in the Oyo Zone.All sensory and non-sensory indicators of fish quality were however within acceptable limits in the four zones of Oyo State.
\end{abstract}

Key words: Frozen fish, Sensory assessment, Chemical assessment, ADP zones, Oyo state.

\section{INTRODUCTION}

In Nigeria, fish whether consumed as frozen, canned or cured represents a significant proportion of the animal protein in the diet. Fish consumption accounts for about 45\% animal protein consumption in Nigeria because fish is less tough and more digestible compared to beef, mutton, chicken and bush meat (Cheke, 2014). Fish flesh is preferable because of a greater ratio of muscle protein of fish to the connective tissue (Oehlenschlager, 1997). Fish is relished because of the high proportion of polyunsaturated fatty acids of the (n-3) family and low cholesterol in its fat content (Sanchez-Alonso and Borderias, 2008).

Food and Agricultural Organization, FAO (2004), however reported fish quality, including safety as a major concern facing the food industry today. Quality deterioration of stored fish is inevitable with length of storage period (Jeon et al., 2002). Spoilage changes result in the gradual accumulation in the flesh of compounds, the quantity of which provides a measure of the progress of spoilage that is independent of sensory assessment.Sensory assessment is the use of one or more of the five senses to judge or form an opinion on some aspects of quality. The senses in question are sight, smell, taste, touch and hearing (FAO/Codex, 1999).As fish spoils, it goes through a sequence of changes that are readily detectable by the human sense of sight, touch, smell and taste (Aitken et al., 1982). The spoilage compound is the trimethylamine (TMA) derived possibly partly by intrinsic enzymes, but certainly by bacteria action from trimethylamine oxide (TMAO) (Connell, 1995).Hypoxanthine is a degradation product of adenosine triphosphate and its level in a fish is an indication of the extent of spoilage (Kirk and Sawyer, 1999).

The energy intensive freezing operation is only a temporary method of preservation of fish as freeze storage can decrease microbial and enzymatic spoilage but cannot prevent oxidative 
spoilage (Ghaly et al., 2010).During the frozen storage of fish, lipid hydrolysis and oxidation have been shown to occur (Verma et al., 1995). These lipid reactions are known to cause rancidity, protein denaturation and texture changes which affect acceptability of the fish (Mackie, 1993).It has been proven that not all fat changes are mainly oxidative in nature. Some involve the hydrolytic liberation of fatty acids as well as other organic acids. Free Fatty Acid (FFA) formation as a result of lipid (triglyceride and phospholipid classes) hydrolysis has provided a suitable means for assessment of fish damage during frozen storage (Aubourg, 1999).

This study was undertaken principally to evaluate the sensory and chemical composition of the frozen fish sold in selected markets in Oyo State with the aim of predicting their suitability for human consumption.

\section{MATERIALS AND METHODS \\ Sample Collection}

Sardinella species (sardine) and Micromesistius poutassson (blue whiting) were selected from among the commercially important species of imported frozen fish sold in Oyo State. The two fish species were selected due to their availability, spread and acceptability to the consumers in all the four zones (Ibadan/Ibarapa, Ogbomoso, Oyo and Saki). Several samples of Sardinella species and Micromesistius poutasssou with average body weight of $190 \mathrm{~g}$ and length between $25-30 \mathrm{~cm}$ were collected from retail depots from these four zones used for this study.The samples were collected in suitable aluminum foil, placed in sterile plastic containers with ice and immediately taken to the appropriate laboratory for analysis. Sampling was done in the four zones once every two weeks in each of the zone over twelve month's period between January and December.

\section{Organoleptic Assessment}

This assessment was carried out on both the uncooked and the cooked fish samples. Fish samples from different zones were presented bimonthly to a semi-trained five-man panel for organoleptic assessment in a well lit environment free of odour. The fish were presented to the taste panel immediately after purchase from retailers. Assessment was based on the scoring system by
Minim, (2006) which involved measurement of certain parameters on a 7-point hedonic scale for the determination of selected characteristics. The seven categories were ranked as follows: very much liked (7), liked a lot (6), liked (5), liked and did not like (4), disliked (3), much disliked (2) and very much disliked (1).

For the cooked treatment, the fish samples were gutted and steamed whole for about 20 minutes; and allowed to cool to a comfortable tasting temperature. Samples were then presented to the taste panel on a clean plate. For the uncooked treatment, each fish sample was placed on a clean plate for assessment. Each assessor was given a scoring sheet to document their observation. The parameters assessed for the uncooked fish were: appearance or external characteristics (mucus, shape of the eye and rigidity of the abdominal wall, colour of the gills and skin, texture and odour). Cooked fish were assessed using only the texture, odour and taste.

\section{Sample Preparation/Analysis}

The fresh frozen fish samples were blended using a sterilized blender and the blended samples were subsequently analyzed using standard method of AOAC (2002) to determine theHypoxanthine, Peroxide value, Free Fatty Acid and Trimethylamine.

Hypoxanthine was determined colorimetrically using 4-Dimethylaminobenzoic acid solution at a wavelength of $460 \mathrm{~nm}$.Crushed fish samples (2g) was weighed into a $250 \mathrm{ml}$ beaker, $1 \mathrm{~g}$ of active carbon, $100 \mathrm{ml}$ distilled water and $5 \mathrm{ml}$ of Carrez solutions I and II were added and mixed for 30 minutes. The mixture was filtered through a Whatman No. 2 filter paper. Carrez solution I contain potassium hexacyanoferrate (II)trihydrate $\left(\mathrm{K}_{4}\left[\mathrm{~F}(\mathrm{CN})_{6}\right] \times 3 \mathrm{H}_{2} \mathrm{O}\right)$. Concentration: $15 \mathrm{~g} / 100 \mathrm{ml}$. Carrez solutionsII contains zinc sulphateheptahydrate $\left(\mathrm{ZnSO}_{4} \times 7 \mathrm{H}_{2} \mathrm{O}\right)$. Concentration: $30 \mathrm{~g} / 100 \mathrm{ml}$. Concentration started from $0,2,4,6,8,10$.

Peroxide value was volumetric method by titration of the liberated iodine with thiosulphate using starch as an indicator. Crushed fish sample $(2 \mathrm{~g})$ was weighed into a $250 \mathrm{ml}$ beaker. $20 \mathrm{ml}$ of chloroform and $10 \mathrm{ml}$ of glacial acetic acid was 
added to the fish sample in the beaker and mixed. The mixture was filtered into $250 \mathrm{ml}$ conical flask, $1 \mathrm{ml}$ of $5 \%$ (aq) saturated potassium iodide (KI) solution was added and shaken thoroughly. The homogenous mixture was placed on the hot plate to boil for 30 seconds. $25 \mathrm{ml}$ distilled water was added and shaken; $1 \mathrm{ml}$ of $1 \%$ starch was added and the hot mixture titrated against the $0.002 \mathrm{M}$ $\mathrm{Na}_{2} \mathrm{SO}_{3}$. A blank determination was also carried out at the same time.

Titrimetric method was used in determining Free Fatty Acid. Well- macerated fish sample (1g) was weighed into a $100 \mathrm{ml}$ beaker. $50 \mathrm{ml}$ of chloroform was added and stirred with a mechanical stirrer for 5 minutes to ensure a complete extract of fat from the fish flesh sample. The mixture was filtered through a Whatman No.1 filter paper into a $250 \mathrm{ml}$ conical flask. $25 \mathrm{ml}$ of the filterate was dissolved in $25 \mathrm{ml}$ of mixed neutral solvent (mixture of diethylether and alcohol neutralized with $0.1 \mathrm{~N}$ $\mathrm{NaOH}$ at ratio $1: 1.1 \mathrm{ml}$ of $1 \%$ phenolphthalein solution was added and titrate against $0.1 \mathrm{~N} \mathrm{NaOH}$ until a pink colour, which persisted for 15 seconds was obtained.

$$
\% \mathrm{FFA}=\frac{\mathrm{VxNx} 282}{\mathrm{~W}} \times 100
$$

Trimethylamine was measured by colorimetric method using Resolic acid solution as indicator.A well ground fish sample (2g) was homogenized with $60 \mathrm{ml}$ of $5 \%$ TCA (Tetrachloroacetic acid). The mixture was properly homogenized to obtain uniform slurry. The slurry was filtered into a $50 \mathrm{ml}$ volumetric flask to obtain a clear filtrate. $5 \mathrm{ml}$ of the clear filtrate was pipetted into a semi-micro distillation apparatus to which $5 \mathrm{ml}$ of $2 \mathrm{M} \mathrm{NaOH}$ was added. The mixture was then steam-distilled in the distillation apparatus into $15 \mathrm{ml}$ of $0.01 \mathrm{M}$ $\mathrm{HCl}$ solution in $50 \mathrm{ml}$ conical flasks. $1 \mathrm{ml}$ of Resolic acid indicator solution was added to give a bluish colour. The mixture was then titrated to give a pale pink end point with $0.01 \mathrm{M} \mathrm{NaOH}$ solution to obtain $\mathrm{V}_{1}$. Note that to every $10 \mathrm{ml}$ liquid in the titration flask, $1 \mathrm{ml}$ of $16 \%$ neutralized formaldehyde solution was added. $1 \mathrm{ml}$ of $16 \%$ formaldehyde (neutralized) was added to the mixture in the titration flask to liberate excess acid.
The excess acid was titrated with $0.01 \mathrm{M} \mathrm{NaOH}$ to obtain $\mathrm{V}_{2}$.

$$
\mathrm{TMA}=\frac{14(300+\text { weight of sample taken }) \mathrm{xV}_{2}}{\text { Nitrogen } 500}
$$

\section{Statistical Analysis}

The statistical programme, (SPSS, 2003) VERSION 16.0 was used to analyse the result of the treatments. Descriptive statistics were used to analyze the data collected while T-test was used to determine the differences in the quality parameters of the two frozen fish species examined.

\section{RESULTS \\ Sensory Evaluation}

The mean hedonic scores obtained for the taste, odour, texture, appearance, colour and overall acceptability of the two fish samples are presented in Table 1. Sardinella spp. samples from Oyo Zone had the least values in taste $(5.67 \pm 0.21)$, odour (5.67 \pm 0.21$)$, texture $(5.50 \pm 0.22)$, appearance $(5.33 \pm 0.33)$ and colour $(5.17 \pm 0.40)$ across the four zones. The highest values for taste $(6.17 \pm 0.30)$ and colour $(5.83 \pm 0.16)$ was recorded in Saki Zone, Ogbomoso Zone in texture $(6.00 \pm 0.25)$ while values for appearance $(5.67 \pm 0.21)$ and odour $(5.83 \pm 0.16)$ were highest in both Ogbomoso and Saki zones respectively. $M$. poutasson recorded the lowest values in taste $(5.75 \pm 0.25)$ and odour (5.67 \pm 0.18$)$ from fish samples collected from Ibadan/Ibarapa Zones, while the lowest values for texture, appearance and colour were 5.50 \pm 0.22 (Ogbomoso and Oyo), $5.33 \pm 0.21$ (Ogbomoso) and 5.00 \pm 0.22 (Saki) respectively. The highest value for taste $(6.17 \pm 0.16)$ was recorded for $M$. poutassou samples in Ogbomoso Zone, while Saki Zone had highest value in odour $(6.00 \pm 0.25)$, texture $(5.67 \pm 0.21)$, appearance $(5.67 \pm 0.21)$ and colour $(5.83 \pm 0.16)$ across the four zones respectively. The mean acceptability values were within a range of $5.47 \pm 0.20$ (Оyo) - 5.90 \pm 0.08 (Saki) recorded for Sardinella spp. and $5.57 \pm 0.13$ (Оyo) - 5.80 \pm 0.10 (Saki) for M. poutassou respectively. However, there were no significant differences $(\mathrm{p}>0.05)$ between the mean acceptability scores recorded for the two species across the zones (Table 3 ). 
Table 1. Mean Hedonic scores for Sardinella spp. and Micromesistius poutassou samples across the zones in Oyo State

\begin{tabular}{|c|c|c|c|c|c|c|c|c|}
\hline \multirow{3}{*}{$\begin{array}{l}\text { Physical } \\
\text { parameters }\end{array}$} & \multicolumn{7}{|c|}{ Zone } & \multirow[b]{3}{*}{ M. poutasson } \\
\hline & Ibadan/ & & Ogbomoso & & Оуо & & Saki & \\
\hline & $\begin{array}{l}\text { Sardinella } \\
\text { spp. }\end{array}$ & $\begin{array}{l}M . \\
\text { poutassou }\end{array}$ & $\begin{array}{l}\text { Sardinella } \\
\text { spp. }\end{array}$ & $\begin{array}{l}\text { M. } \\
\text { poutassou }\end{array}$ & $\begin{array}{l}\text { Sardinella } \\
\text { spp. }\end{array}$ & $\begin{array}{l}\text { M. } \\
\text { poutassou }\end{array}$ & $\begin{array}{l}\text { Sardinella } \\
\text { spp. }\end{array}$ & \\
\hline Taste & $5.83 \pm 0.16$ & $5.75 \pm 0.25$ & $6.17 \pm 0.16$ & $6.17 \pm 0.16$ & $5.67 \pm 0.21$ & $6.00 \pm 0.25$ & $6.17 \pm 0.30$ & $5.83 \pm 0.30$ \\
\hline Odour & $5.75 \pm 0.17$ & $5.67 \pm 0.18$ & $5.83 \pm 0.16$ & $5.67 \pm 0.21$ & $5.67 \pm 0.21$ & $5.83 \pm 0.16$ & $5.83 \pm 0.16$ & $6.00 \pm 0.25$ \\
\hline Texture & $5.67 \pm 0.14$ & $5.67 \pm 0.18$ & $6.00 \pm 0.25$ & $5.50 \pm 0.22$ & $5.50 \pm 0.22$ & $5.50 \pm 0.22$ & $6.00 \pm 0.00$ & $5.67 \pm 0.21$ \\
\hline Appearances & $5.50 \pm 0.23$ & $5.67 \pm 0.18$ & $5.67 \pm 0.21$ & $5.33 \pm 0.21$ & $5.33 \pm 0.33$ & $5.50 \pm 0.22$ & $5.83 \pm 0.16$ & $5.67 \pm 0.21$ \\
\hline Colour & $5.25 \pm 0.25$ & $5.42 \pm 0.22$ & $5.33 \pm 0.42$ & $5.33 \pm 0.21$ & $5.17 \pm 0.40$ & $5.00 \pm 0.00$ & $5.67 \pm 0.21$ & $5.83 \pm 0.16$ \\
\hline Overall & & & & & & & & \\
\hline Acceptability & $5.60 \pm 0.15$ & $5.63 \pm 0.11$ & $5.80 \pm 0.12$ & $5.60 \pm 0.13$ & $5.47 \pm 0.20$ & $5.57 \pm 0.13$ & $5.90 \pm 0.08$ & $5.80 \pm 0.10$ \\
\hline
\end{tabular}

\section{Chemical Evaluation \\ Peroxide Value and Free Fatty Acid Concentration}

Results indicated that frozen fish samples obtained from Oyo Zone had the lowest peroxide values in both the Sardinella species $(17.48 \pm 0.81 \mathrm{meq} / \mathrm{kg}$ ) and $M$. poutassou $(17.90 \pm 0.60 \mathrm{meq} / \mathrm{kg})$. Frozen fish samples from Ogbomoso Zone had the highest PV $(18.83 \pm 0.60 \mathrm{meq} / \mathrm{kg})$ for the Sardinella spp. compared to $M$. poutassou samples from Saki Zone $(19.79 \pm 1.03 \mathrm{meq} / \mathrm{kg})$. The peroxide concentration in the frozen fish samples was generally lower for the Sardinella spp. obtained from the four zones than $M$. poutassou samples (Table 2).

Ogbomoso Zone had the highest mean concentration of FFA $(1.85 \pm 0.31 \% ; 1.82 \pm 0.19 \%)$ in both the Sardinellaspp. and M.poutasssou respectively. The lowest mean FFA value was however recorded in the samples collected from the Ibadan/Ibarapa Zone (1.52 $\pm 0.14 \%$; $1.38 \pm 0.07 \%$ ) respectively. Sardinella spp. had higher FFA values in Ibadan/Ibarapa, Ogbomoso and Oyo zones when compared with $M$. poutasssou. The only exception was recorded in the samples of the species collected from the Saki Zone.

\section{Trimethylamine level}

The mean concentration of TMA in the two species by zones (Table 2) showed that frozen fish samples of $M$. poutassou from Ibadan/Ibarapa
Zone had the highest concentration of TMA $(22.96 \pm 0.49 \mathrm{mg} / 100 \mathrm{~g})$, followed by the samples of the fish from Saki Zone $(21.79 \pm 3.32 \mathrm{mg} / 100 \mathrm{~g})$ while the least values was recorded in the fish sample collected from the Oyo Zone (19.03 0.65 $\mathrm{mg} / 100 \mathrm{~g})$. In Sardinella spp., the highest concentration of TMA was recorded in samples of the fish collected from Ogbomoso Zone $(23.63 \pm 0.89 \mathrm{mg} / 100 \mathrm{~g})$ while the lowest $(20.58 \pm 0.90 \mathrm{mg} / 100 \mathrm{~g})$ was recorded in the samples from the Oyo Zone.

\section{Hypoxanthine Level}

Hypoxanthine levels were higher inM. Poutasssou samples collected from all the zones compared with those of Sardinella spp. The highest hypoxanthine values for both Sardinella spp. and $M$. poutassou were recorded in frozen fish samples collected from the Oyo Zone $(25.54 \pm 0.41 \mathrm{mg} / 100 \mathrm{~g}$ and $25.96 \pm 0.53 \mathrm{mg} / 100 \mathrm{~g})$ respectively. The lowest hypoxanthine level (22.15 $\pm 1.04 \mathrm{mg} / 100 \mathrm{~g})$ in Sardinella spp. samples was recorded from Saki Zone andfor $M$. poutasson samples $(25.49 \pm 0.65 \mathrm{mg} / 100 \mathrm{~g})$ collected from Ibadan/Ibarapa Zone. The mean values of the quality indices in the two fish species (Table 3) showed that there were no significant differences $(p>0.05)$ in the organoleptic parameters, PV, TMA and FFA levels. However, the mean hypoxanthine levels between the two species was significantly different $(\mathrm{p}<0.05)$ from each other. 
Table 2.Mean concentration of chemical parameters in Sardinella spp. and M. poutassou samples across Zones in Oyo State.

\begin{tabular}{|c|c|c|c|c|c|}
\hline Fish species & Zones & $\begin{array}{c}\mathrm{PV} \\
(\mathrm{meq} / \mathrm{kg})\end{array}$ & $\begin{array}{l}\text { TMA } \\
(\mathrm{mg} / 100 \mathrm{~g})\end{array}$ & $\begin{array}{l}\text { FFA } \\
(\%)\end{array}$ & $\begin{array}{l}\mathrm{Hx} \\
(\mathrm{mg} / 100 \mathrm{~g})\end{array}$ \\
\hline $\begin{array}{l}\text { Sardinella } \\
\text { spp. }\end{array}$ & $\begin{array}{l}\text { Ibadan/Ibarapa } \\
\text { Ogbomoso } \\
\text { Oyo } \\
\text { Saki }\end{array}$ & $\begin{array}{l}18.52 \pm 0.55 \\
18.83 \pm 0.60 \\
17.48 \pm 0.81 \\
18.50 \pm 1.69\end{array}$ & $\begin{array}{l}23.07 \pm 0.65 \\
23.63 \pm 0.60 \\
20.58 \pm 0.90 \\
22.79 \pm 3.02\end{array}$ & $\begin{array}{l}1.52 \pm 0.14 \\
1.85 \pm 0.31 \\
1.73 \pm 0.27 \\
1.53 \pm 0.17\end{array}$ & $\begin{array}{l}24.48 \pm 0.56 \\
24.47 \pm 0.77 \\
25.54 \pm 0.41 \\
22.15 \pm 1.04\end{array}$ \\
\hline $\begin{array}{l}\text { Micromesistius } \\
\text { Poutasssou }\end{array}$ & $\begin{array}{l}\text { Ibadan/Ibarapa } \\
\text { Ogbomoso } \\
\text { Oyo } \\
\text { Saki }\end{array}$ & $\begin{array}{l}19.47 \pm 0.42 \\
19.56 \pm 0.75 \\
17.90 \pm 0.60 \\
19.79 \pm 1.03\end{array}$ & $\begin{array}{l}22.96 \pm 0.49 \\
19.89 \pm 1.66 \\
19.03 \pm 0.65 \\
21.79 \pm 3.32\end{array}$ & $\begin{array}{l}1.38 \pm 0.07 \\
1.82 \pm 0.19 \\
1.69 \pm 0.22 \\
1.67 \pm 0.19\end{array}$ & $\begin{array}{l}25.49 \pm 0.65 \\
25.69 \pm 1.01 \\
25.96 \pm 0.53 \\
25.77 \pm 0.49\end{array}$ \\
\hline $\begin{array}{l}\text { International } \\
\text { Standards }\end{array}$ & & $\begin{array}{l}10-20 \\
\mathrm{meq} / \mathrm{kg}\end{array}$ & $30 \mathrm{mg} / 100 \mathrm{~g}$ & $1.85 \%$ & $29.58 \mathrm{mg} / 100 \mathrm{~g}$ \\
\hline
\end{tabular}

Table 3.T- Test for Mean values of Quality indices in Sardinella spp. and M. poutassou samples across Zones in Oyo State.

\begin{tabular}{|c|c|c|c|c|c|c|}
\hline Parameter & Fish species & $\mathrm{N}$ & $\bar{x} \pm S E M$ & Df & t-value & P Level \\
\hline Organoleptic & $\begin{array}{l}\text { Sardinella spp. } \\
\text { M. poutasssou }\end{array}$ & 30 & $\begin{array}{l}5.67 \pm 0.08 \\
5.65 \pm 0.06\end{array}$ & 58 & 0.26 & 0.795 \\
\hline Peroxide value ( meq/kg) & $\begin{array}{l}\text { Sardinella spp. } \\
\text { M. poutasssou }\end{array}$ & 30 & $\begin{array}{l}18.38 \pm 0.43 \\
19.24 \pm 0.34\end{array}$ & 58 & -1.58 & 0.120 \\
\hline Trimethylamine $(\mathrm{mg} / 100 \mathrm{~g})$ & $\begin{array}{l}\text { Sardinella spp. } \\
\text { M. poutasssou }\end{array}$ & 30 & $\begin{array}{l}22.63 \pm 0.69 \\
21.33 \pm 0.55\end{array}$ & 58 & 1.48 & 0.145 \\
\hline Free fatty acid (\%) & $\begin{array}{l}\text { Sardinella spp. } \\
\text { M. poutasssou }\end{array}$ & 30 & $\begin{array}{l}1.63 \pm 0.11 \\
1.59 \pm 0.08\end{array}$ & 58 & 0.30 & 0.768 \\
\hline Hypoxanthine(mg/100g) & $\begin{array}{l}\text { Sardinella spp. } \\
\text { M. poutasssou }\end{array}$ & 30 & $\begin{array}{l}24.23 \pm 0.40 \\
25.68 \pm 0.35\end{array}$ & 58 & -2.78 & $0.007^{*}$ \\
\hline
\end{tabular}

* Significantly different at $\mathrm{p}<0.05$

\section{DISCUSSION}

The organoleptic properties of the examined frozen Sardinella spp. and M. poutassou samples collected from the four zones of Oyo State indicated that the products were acceptable according to the panel's evaluation using 7-point Hedonic scale designed by Minim(2006).

Lakshmanan (2000) posited that the acceptable limitof Peroxide value in fish should be between $10-20 \mathrm{meq} / \mathrm{kg}$ values, above which afish would probably smell and taste rancid. However, the peroxide values for frozen fish recorded across the four zones of the state fell within this limit.Frozen fish from the Oyo Zone with the lowest PV of
17.48 and 17.90 for both Sardinella spp. and $M$. poutassou respectively, had the lowest tendency to go rancid.In the same vein, Free Fatty Acid concentration in both frozen fish samples from across the zones, were found to be within the acceptable limit of $1.8 \%$ established by Oyelese (2012).Trimethylamine according to Connell and Shewan (1980)is a well accepted indicator of freshness or spoilage in marine fishes. The TMA level in the two frozen fish samples across zones of Oyo State fell within the acceptable limit of $30 \mathrm{mg} / 100 \mathrm{~g}$ fish recommended by Regenstein et al. (1982).

Hypoxanthine is an important parameter used for 
estimation of wholesomeness or otherwise of fishes. It begins to accumulate shortly after the death of fish and it increases with storage time (Nakatami et al., 2005). Hypoxanthine level in the two frozen fish samples from the four designated zones of the state wasalso within acceptable limits of $29.58 \mathrm{mg} / 100 \mathrm{~g}$ fish as reported by Oyelese (2012). The results obtained agreed with previous studies by Howgate (1982), Watanabe et al. (1983), Yao (1993), Niu and Lee (2000). Theauthors reported that hypoxanthine concentration increases with storage time making it a good predictor of spoilage over a wide range of quantities and it is best suited for a wide range of species products than both TMA and total volatile base (TVB).Metin et al. (2001) also stated that organoleptic spoilage became obvious at the highest level of hypoxanthine. In the present studyhowever, the significant difference $(p<0.05)$ in the total mean concentration of hypoxanthine levels in the two fish species across zones marked differences between Sardinella spp. and $M$. poutassou. All the chemical parameters ( $\mathrm{Hx}, \mathrm{PV}$, FFA and TMA) assayed, which were within the acceptable limits, probably reflected the high overall acceptability of the two frozen fish species in Oyo State.

\section{CONCLUSION}

The organoleptic properties of the examined samples from the two species showed thatthe fishes were acceptable in Oyo State. However, detailed chemical studies provedthat the two frozen fishes had the best keeping quality in the Oyo Zone,while frozen fishes from Ogbomoso Zone had the least quality amongst the four zones in the state.

\section{ACKNOWLEDGEMENTS}

Our express gratitude to Prof. B. O. Omitoyin, Prof. E. K. Ajani, Dr. (Mrs.) O.O. Olusola and Dr. (Mrs.) F.O.A. George for their technical assistance at making this research a success.

\section{REFERENCES}

Aitken, A., Mackie, I.M., Merrit, J.H. and Windsor, M.L. 1982. Fish Handling and Processing. HMSO Edinburgh. Pp 167-186.

AOAC. 2002. Official Methods of Analysis of the Association of Official Analytical Chemists (1 $7^{\text {th }}$ Edition). Virginia. 1298pp.
Aubourg, S.P. 1999. Lipid damage detection during the frozen storage of an underutilized fish species. Food Research International, 32 (7): 497-502.

Cheke, A. O. 2014. Markets and marketing of fish and fishery products in Nigeria.IIFET 2014 Australia Conference Proceeding.

Connell J.J. 1995. Control of Fish Quality.4th edition. Farnham, England. 245pp.

Connell J.J. and Shewan J.M. 1980.Past, present and future of fish science. Advances in Fish Science and Technology.Fishing news book.Pp30-63.

FAO/Codex 1999.Guidelines for the sensory evaluation of fish and shellfish laboratories. CAC/GL 31:3-33.

Food and Agriculture Organization (FAO). 2004. Assessment and management of seafood safety and quality. Fisheries Technical Paper 444. Pp1.

Ghaly, A.E., Dave, D., Budge, S and Brooks, M.S. (2010).Fish Spoilage Mechanism and preservation Techniques: Review. American Journal of Applied Sciences. 7(7):859-877.

Howgate, P.F. 1982. Fish handling and processing. Torry Research Station. HMSO Press.Pp2042.

Jeon, Y.J., Kamil, J.Y. and Shahidi, F. 2002. Chitosan as an edible invisible film for quality preservation of Herring and Atlantic cod.J. Agric. Food Chem. 50(18): 5167-5178.

Kirk, S.R and Sawyer, R. 1999. Pearson's composition and analysis of foods. Edn. Longman, UK. $9^{\text {th }}$ Edition.Pp 504-525.

Lakshmanan, P.T. 2000. Fish spoilage and quality assessment. In: Quality Assurance in Seafood Processing T.S.G. Iyer, M.K. Kandoran, M. Thomas, and P.T. Mathew. Eds. Cochin: Society Fisher Techno., India. Pp 26-40.

Mackie, I. 1993. The effects of freezing on flesh proteins.Food Reviews International 9: 575610.

Metin, S., Erkan N. and Varlik, C. 2001. The application of Hypoxanthine activity as a quality indicator of cold stored fish burger.Research article, Istanbul University, Turkey.

Minim, V.P.R. 2006. AnaliseSensorial: Estudo Com Consumidores. Vicosa: Editora da Universidade Federal de Vicosa. 225pp.

Nakatami, H. S., Santos, L.V., Pelegrine, C.P., 
Gomes, S.T., Matsushita, M., Sousa, N.L and Visentainer, J.V. 2005. Biosensor based on Xanthine Oxidase for Monitoring hypoxanthine in fish meat. American Journal of Biochemistry and Biotechnology. 1 (2):85-89.

Niu, J and Lee, J.Y. 2000. Bulk modified amperometric biosensors for hypoxanthine based on sol-gel technique. Sensor Actuat. B. Chem. 62:190-198.

Oehlenschlager, J. 1997. Marine fish- A source for Essential Elements?In: Seafood from Producer to Consumer, Integrated Approach to Quality. Luten, J.B., T. Borresen and J. Oehlenschlager Eds. Elsevier Science Publishers B.V. Amsterdam, Netherlands. Pp 641-652.

Oyelese, O.A. 2012. Hypoxanthine levels, chemical studies and bacterial flora alternate frozen/thawed market simulated marine fish species. Progress in food preservation. $1^{\text {st }}$ Edition.

Regenstein, J.M., Schlosser, M.A., Samson, A. and Fey, M. 1982.Chemical changes of trimethylamine oxide during fresh and frozen storage of fish.In: Chemistry and
Biohemistry of marine Food Products. R.E. Martins, G.J. Flick, C.F. Hubard and D.R. Ward. Eds. Westport, Connecticut, 137148.

Sanchez-Alonso, I and Borderias, A. 2008. Technological effect of red grape antioxidant dietaryfibre added to minced fish muscle.Journal of Food Science and Technology. 43: 1009-1018.

SPSS. 2003. Statistical package for social science for Windows 16. SPSS Inc., Chicago, IL, and USA.

Verma, J., Srikar, L., Sudhakara, N. and Sarma J. 1995. Effects of frozen storage on lipid freshness parameters and some functional properties of oil sardine (Sardinellalongiceps) mince. Food Research International, 28: 87-90.

Watanabe, E; Ando, K., Karube, I.; Matsuoka, H and Suzuki, S. 1983. Determination of hypoxanthine in fish meat with an enzyme sensor.J. Food Sci. 48: 496-500.

Yao, T. 1993. Enzyme electrode for the successive detection of hypoxanthine and inosine. Anal. Chim. Acta. 281:323-326. 